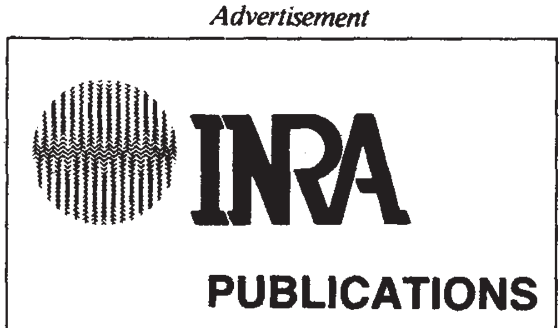

Just published

Animal Production

Le Cheval : reproduction, allmentation, exploitation

1984, 692 p.

$250,00 \mathrm{~F}$

Prix de lancement

Physiologie ot pathologie périnatales chez les animaux de ferme

1984, $474 \mathrm{p}$.

$195,00 \mathrm{~F}$

Insémination artificielle et amélioration génétique : bilan et perspectives critiques

Colloque Toulouse, novembre 1983

1985, $368 \mathrm{p}$.

$140,00 \mathrm{~F}$

Les maladies de la chèvre. Goat

diseases.

Colloque international, Niort, octobre 1984 $1984,750 \mathrm{p}$

$270,00 \mathrm{~F}$

The reproductive potentlal of cattle and shoep. Le potentiel de reproduction des bovins et des ovins.

Joint Israeli-French symposium, Rehovot

(Israël), February 1984.

$1984,413 \mathrm{p}$.

$150,00 \mathrm{~F}$

Plant Production

Les essais de fertllisation de longue duree de la station agronomique de Grignon - Résultats expérimentaux (période 1938-1982)

R. MOREL, Th. LASNIER, S. BOURGEOIS 1984, $335 \mathrm{p}$.

$120,00 \mathrm{~F}$

Physiologie du maîs. Colloque Royan A. GALLAIS éd.

$1984,574 \mathrm{p}$.

$240,00 \mathrm{~F}$

La conservation des ceréales en France. Compte-rendu d'actions pluridisciplinaires, 1980-1982

1984, $171 \mathrm{p}$.

Les cultures hors-sol

1985, $410 \mathrm{p}$.

$60,00 \mathrm{~F}$

Petite paysannerie en France

G. JEGOUZO

$1984,232 \mathrm{p}$.

$130,00 \mathrm{~F}$

Variation et variabillté des agents phytopathogènes. 26 tme colloque de la Société française de Phytopathologie. Avignon, mai 1984.

1984, $235 \mathrm{p}$.

$90,00 \mathrm{~F}$

$6^{\circ}$ conférence européenne et méditerranéenne sur les rouilles des céréales. Grignon, septembre 1984

$1984,223 p$.

$110,00 \mathrm{~F}$

INSTITUT NATONAL DE LA RECHERCHE AGRONOWQUE Service des Publications - Rte de St-Cyr 78000 Versailles

Télex : INRAPUB 6993685

\section{Larger than life}

\section{R.C. Lewontin}

On Being the Right Size and Other Essays.

By J.B.S. Haldane. Edited by John Maynard Smith.

Oxford University Press: 1985. Pp. 187.

Pbk £4.95, \$6.95.

I MUST confess that when I first met J.B.S Haldane I thought him a bit of a humbug. Dressed in his dhoti, smoking a twisted black Burmese cigar and addressing a group of admirers in a Dutch café, he seemed unreal. Nor was I alone in that opinion. Once in an American department store where we had gone to buy some things for Helen Spurway, Haldane pulled out an Indian rupee note, announcing to the sales clerk "I'm a Hindu, you know". As he left, she turned to me and said "That's funny. I could have sworn he was one of those highclass Englishmen".

But, of course, Haldane was vastly more than a showman. He was the most incisive and wide-ranging intellect I have ever known, original, iconoclastic, a master at making connections between apparently unrelated phenomena, and by far the best popular science writer who has ever addressed an English-speaking readership. All these aspects are displayed in this collection of his essays, chosen with great judgement by his former student and colleague John Maynard Smith, essays ranging from the origin of life and the gods, to the Last Judgement, somewhere around the year $36,000,000$. In between Haldane explains in plain English what "hot" means, how the organism is produced by interaction of its genes and its developmental environment, why one can survive for hours shut up in an air-tight box and how capitalism has made a commodity out of health. Written as clearly as they are, these essays tempt the reader to take them all at one sitting, but I advise against it. The best prescription is one a day followed by deep thought.

Haldane the humbug shows up occasionally, as when he quotes extensively from the Norse epic Volospa in the original, a bit of flummery that can only be meant to give an impression of fluency in an esoteric language. Yet it seems so unnecessary. Haldane was a person of genuinely wide learning, as shown, for example, in the essay "Is History a Fraud", where a variety of historical detail is displayed in the service of a central idea: the superiority of the practical over the merely intellectual. It is a sign of the contradiction that marked Haldane's world view that he could prefer Pasteur above Darwin because the former solved a "practical problem of living", yet at another time could praise an idea as "interesting, even if not true".

Haldane the critical scientist comes out best in "The Biology of Inequality" which shows a subtlety of understanding of the relationship between gene, environment and organism that is, even today, absent from the thinking of most biologists. Yet here again is a contradiction. Haldane makes clear in this essay that it is not the phenotype, but the pattern of reaction to a contingent environment that is inherited. Yet earlier, in "The Future of Biology", he writes of "the main gene that determined his father's mathematical powers". Nor was it simply wisdom acquired in the ten years between these essays. To the end of his life, Haldane remained committed to a hereditarianism in regard to human psychic development, a biological determinism that may seem strange in

\section{IMAGE \\ UNAVAILABLE \\ FOR COPYRIGHT REASONS}

Public faces - Haldane addressing a "United Front" meeting in Trafalgar Square, 1937 (right), and at the Indian Statistical Institute, Calcutta. The pictures are reproduced from J.B.S., Ronald Clark's biography which was re-issued in paperback last year by Oxford University Press. 
someone who claimed to be a revolutionary socialist. The key to this apparent paradox can be found in what appears to be Haldane's preoccupation with religion.

In essay after essay in this collection Haldane returns to the subject of religion. It is not simply that the editor has chosen essays on religious subjects, such as "When I am Dead", "God-makers" and "Science and Theology as Art Forms". Haldane brings in Christianity, Hinduism, religious myth in general and an Egyptian fakir in particular as integral to the points he is making about history and science. To understand why this is so, we must realize that Haldane was born in the last years of Victoria's reign and his intellect was formed in the Edwardian period. The primary intellectual struggle in his view, a view shared by Marxists of the 1930s, was the struggle between materialism and philosophical idealism. Marxism for Haldane, as for H.J. Muller, meant the fight to overturn the superstition, both scientific and social, that marked nineteenth century ideology, and its replacement by a materialist, scientific society. Part of that materialism was a belief that biological technology including eugenic measures could be instrumental in putting society on a better basis. The view seems naive to us now. If biology is to be relevant to reorganizing society, it must be the biology of what is in our heads, not what is in our gonads. Nevertheless, we must side with Haldane's desire to replace mystifying social myths by rational realities.

R. C. Lewontin is a Professor of Biology in the Museum of Comparative Zoology, Harvard University.

\section{Schools of thought}

\section{Struther Arnott}

\section{Graduate Research: A Guide for}

Students in the Sciences.

By Robert V. Smith.

ISI Press, 3501 Market Street,

Philadelphia: 1984. Pp.182. Hbk \$21.95

(North America), $\$ 24.95$ (elsewhere); pbk $\$ 14.95$ (North America), $\$ 17.95$ (elsewhere).

HERE is a programme instructing the ambitious mediocracy how to apprentice themselves to the trade of being a (US) scientific worker. It begins at the same inspirational level as it continues with the thought that "it is crucial for graduate students in the sciences to master this skill [in research] because their advanced degrees depend upon it'. It concludes with the optimistic and self-congratulatory assurance that "you should expect to find a good position".

This is a "how to" manual with a vengeance: how to get started; how to choose a research field and a mentor; how to manage time and libraries; how to write dissertations and papers; how to get grant support and a job; even how to note rather than to take cognizance of and how to prepare a consent form for research on human subjects. Thank goodness the chapters on ethics and creativity are not "how to" ones. But there we are regaled with a re-run of Kekule's reverie which produced the structure of benzene. Inexplicably absent is the crucial part of the dream where some of the dancing chains of atoms joined ends to form rings. Such persistence in missing the point is a general characteristic of this book.

There is a tidy-minded part of me which was impressed by Dr Smith's thoroughness in mustering many useful thoughts about our graduate schools. I and my colleagues surely would want our doctoral students, potential and actual, to be aware of the management structures in our (usually very large) universities, to be familiar with the various opportunities for financial support, and to be chary of over-involvement in teaching and in passive attendance at courses and seminars. However, not all the wise saws and modern instances are as pleasing. Few of us would dispute that "excessive television is a deterrent to purposeful observation" but would any of us want to be saddled with protégés needing such banal advice or with disciples who would formulate the hypothesis that "sensory deprivation in human subjects is associated with increased alienation and manifested as loneliness" only after a survey comparing deaf and blind widows with widows having normal hearing and sight?

The author does assert at one point that "research... requires certain personal traits and practices. Some characteristics must already be part of the individual, some can be improved with practice". I agree completely. What strains my credulity is the implication that a beginning graduate student typically could have postponed until reading this book the acquisition and development of the traits of a successful scholar or researcher. Yet expectation of perpetual opportunity for educational rehabilitation has been a pervasive ingredient of public policy in the United States for at least a generation. Only recently has there been general recognition of the consequences, such as high schools staffed with inadequately rewarded - and therefore indifferent or demoralized teachers - graduating, not very discriminatingly, 75 per cent of their entering classes. Better paid college professors can thereafter, much more expensively, try to remedy ingrained habits of intellectual indolence. Professors condemned to be ushers do not resist this marketplace philosophy nor strive to maintain system in national educational arrangements. The result is loss of rigour, in secondary and in higher education, and buffeting of both by fads and fashions. My own in- stitution recently suffered from a neap tide of interest in computer science which briefly was the proclaimed major subject of more than half the freshman class in our School of Science. Today, that tide is receding, exposing a floundering population dismayed by its lack of quantitative training, analytical skills and capacity for sustained hard work.

A committee of the American Association of Colleges now has demanded baccalaureate programmes which would ensure that their alumni would reason well, would read, write and speak with distinction,

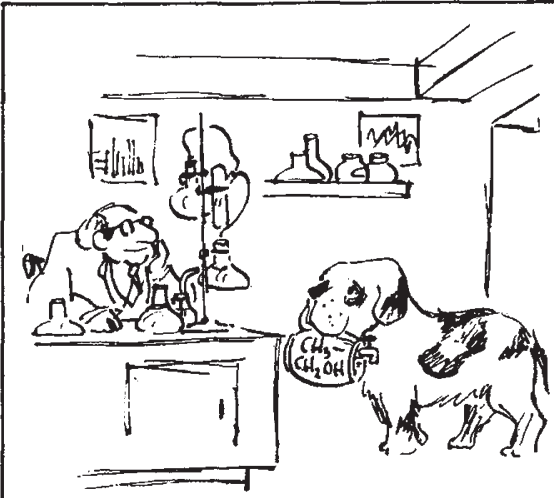

Reproduced from Science Goes to the Dogs, a new collection of cartoons by Sidney Harris published by ISI Press. Price of the book is $\$ 7.95$.

would understand numerical data and the scientific method, and would have historical consciousness and knowledge of the language of the fine arts. Graduate schools, anxious for distinction, will demand at least this, as well as evidence of ability to study in depth which, as the AAC report describes, requires sequential learning, building on blocks of knowledge that lead to more sophisticated understanding and encourage leaps of the imagination and efforts at synthesis.

Now indeed may be the time for us to attend to the quality and configuration of our graduate schools. The main places of employment for holders of the $\mathrm{PhD}$ degree are colleges and universities. Population trends will ensure a 15 per cent fall in the traditional university student population by 1995. Scepticism about the value of some academic qualifications could accelerate this decline substantially. A shift in public policy towards investment in earlier stages of education could make the descent precipitous. Even without a revolution in public policy, there may be less than 100,000 academic positions to be filled in the next decade. Success will fall to those graduate schools which order their requirements and incentives so as to be able to recruit more discriminatingly. In such an environment, Dr Smith's book would be useful only to foreigners curious about some of the minutiae of the academic research environment in the United States. University, Indiana. 